Ann. Zootech., I978, 27 (3), 347-353.

\title{
Udder support as a means for improving milk fractionation in dairy ewes
}

\author{
R. SAGI \\ Faculty of Agricultural Eingineering, \\ Technion-Israel Institute of Technology, Haifa, Israel
}

\section{Summary}

A mechanical supporting arm as a means for increasing the machine milk fraction in dairy ewes was tested. Four groups of ewes having udders of types II and III were subjected to ABA and $\mathrm{BAB}$ treatment sequences. The supporting arm showed a profound effect on the machine nilk and machine stripping fractions. A significant transition of milk $\left(23^{6}+59 \mathrm{ml}\right.$ and $5^{6}$

$92 \mathrm{~m} 1$ ) from the machine stripping to the machine milk fraction was observed in animals witl udder types II and III respectively. The total yield and the hand stripped yield were not affected.

\section{Introduction}

The efficiency of the machine milking of dairy ewes is, quite often, rather limited because of poor milk yield fractionation. In some extreme cases the machine milk fraction (MM) corresponds to only $4^{\circ} \mathrm{p}$. Ioo of the total yield. This is more pronounced in certain breeds, such as the Improved Awassi, and less pronounced in others, such as Sarda.

SAGI and MorAG (I974) showed that the pattern of milk fractionation could be related to udder conformation. It was suggested that, in the long run, improvement of milk fractionation could be achieved through breeding and the selection of dairy ewes with a favoured udder conformation. Since the occurrence of favoured udders is relatively high $-43 \mathrm{p}$. Ioo according to SHarav, Vor.cAnI and EYyL (I962) and 36 p. Ioo according to SAGI and Morag (I974) - breeding seemed. to the authors to be the appropriate and reasonably rapid solution to the problem. Unfortunately, in a later study, JATSCH and SAGI (I978) found that udder conformation does not persist well in dairy ewes and that transition from one type of udder to another may occur in the course of the lactation period. Thus, the number of udders having a favoured conformation is higher at the beginning of the 
lactation period than at its end. Consequently, while breeding and selection is still the correct answer, it will take much longer than predicted, and for a shortterm solution one should look for other means to improve fractionation. SAGI and MORAG (1974) indicated that raising the lower part of the udder by inserting a hand between its two halves, increases the machine milk fraction at the expense of the stripping fractions. The mechanism involved is not yet clear, and the improvement could have been the result of mechanical or physiological factors or of a combination of the two. However, the phenomenon exists and could be utilized for improving milk yield fractionation.

\section{Material and methods}

The effect of supporting the udders of dairy ewes by means of a mechanical spring loaded, supporting device (fig. I) was assessed using 24 weaned, pregnant, Assaf dairy ewes.

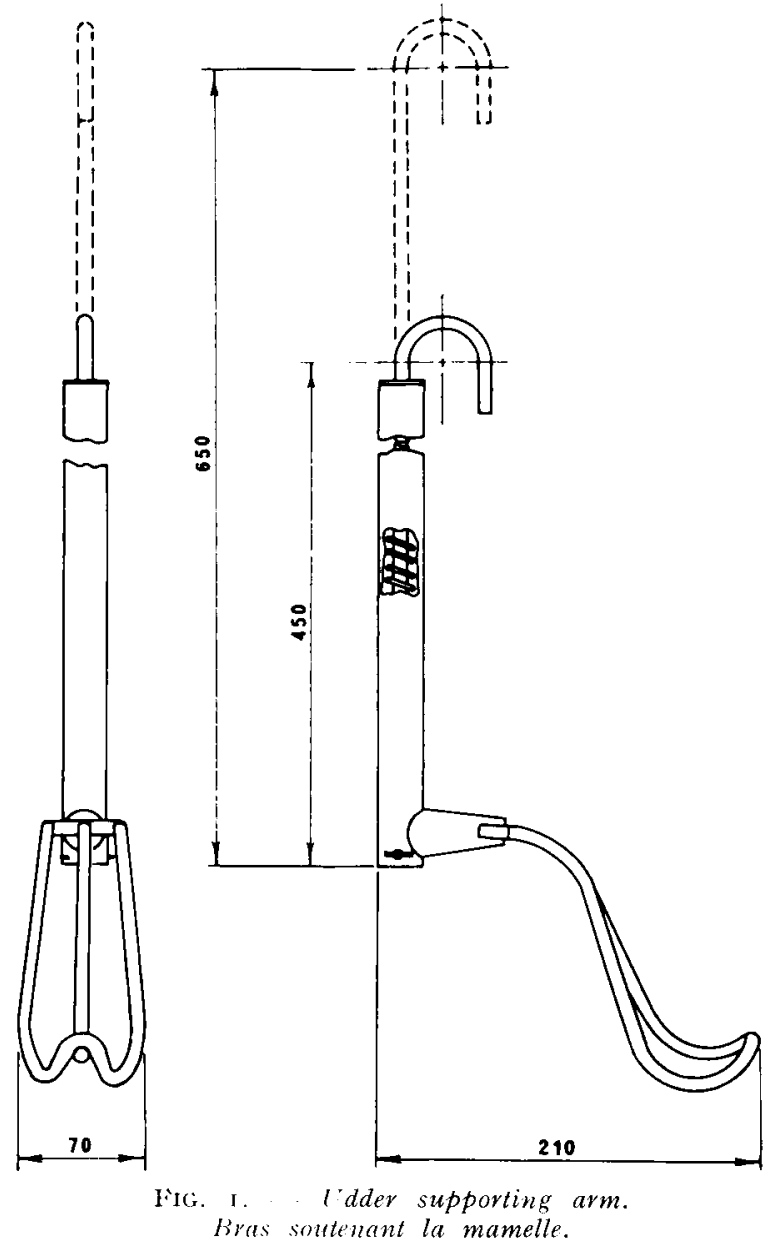


The ewes, which were in their first, second or third lactation period, were selected from the Neve-Ya'ar flock on the basis of their udder conformation. Two groups of 12 animals were formed. The first group comprised animals with type II udders, the second, animals with type III udders.

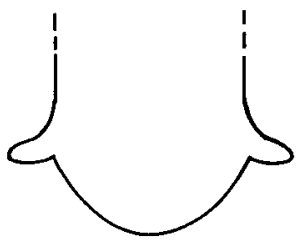

1

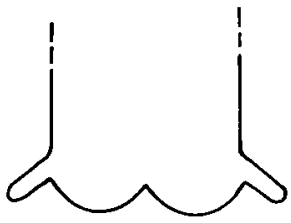

III

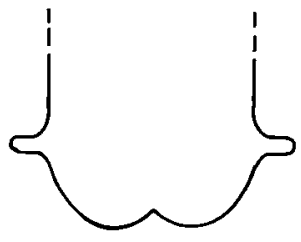

11

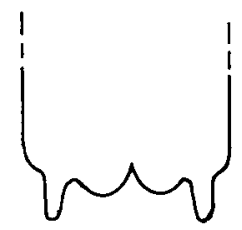

IV

FiIG. 2. - Sichematic representation of udder types $I, I I, I I I$, and $I \mathrm{I}^{\mathrm{T}}$ (after SAGI and MORAG, I974).

Reprisentation sche'matique des différents types de glande mammaire I, II, III ct IV (d'après SAGI et MoRAG, I974).

The ewes in each group were allocated at random to two sub-groups, forming altogether 4 sub-groups, which were subjected to a sequence of switch-back treatments (ABA and $\mathrm{BAB})$. Each period of treatment lasted 5 days. The treatment comprised two milkings a day, at 8 a.m. and at 4 p.m., with (B) and without (A) the use of an udder supporí (fig. 3).

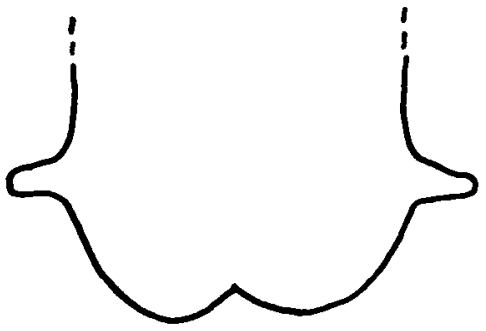

A

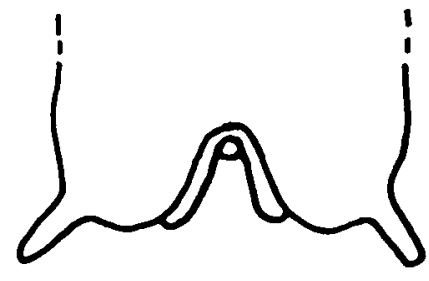

B

FIG. 3. - Schematic representation of treatment $A$ and treatment $B$. Représentation schématique du traitement $A$ et du traitement $B$. 


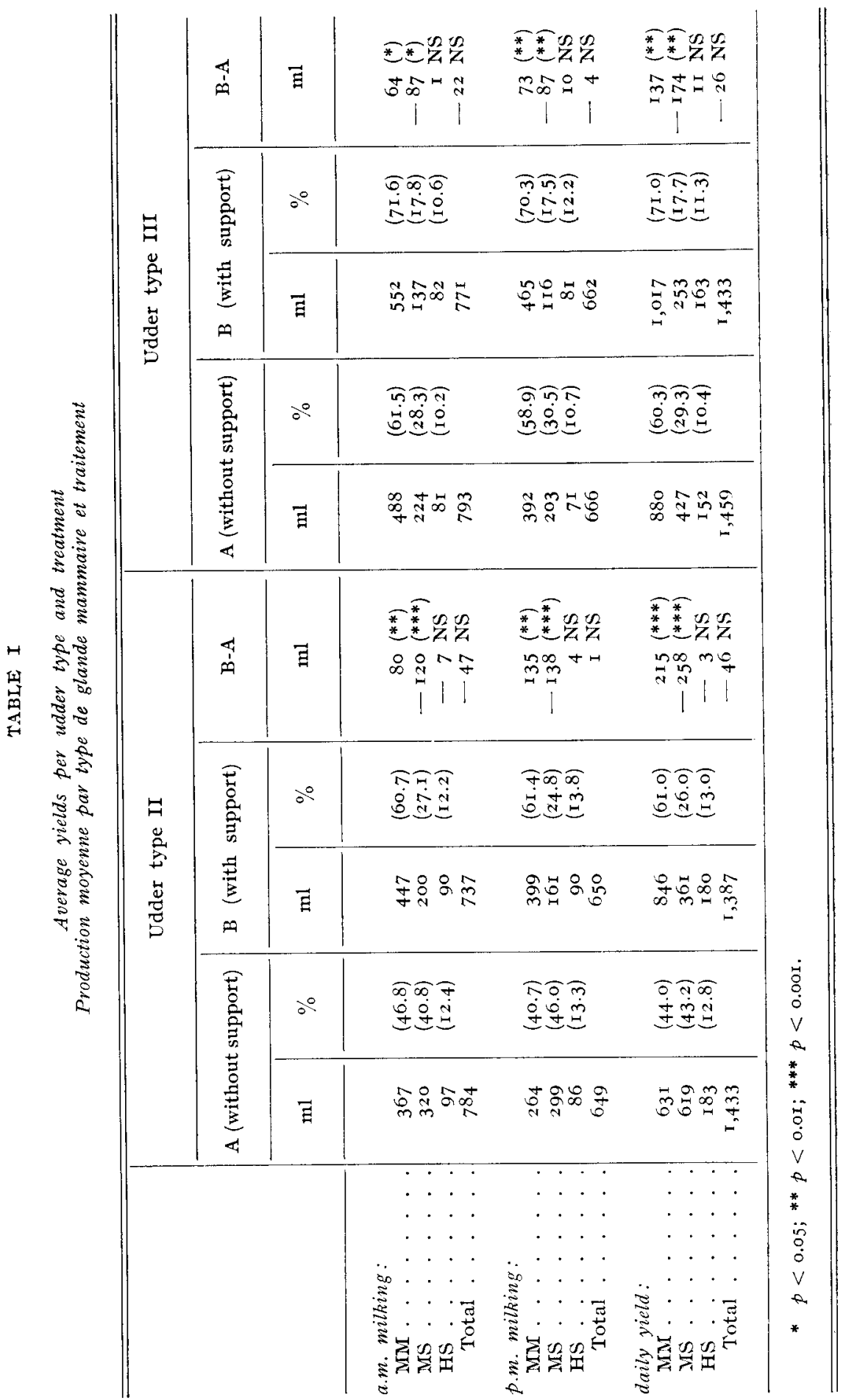


Milk yields were recorded at every milking by means of low-line recording jars which allowed separate estimates of machine milk (MM) and machine stripping (MS) yields. Hand stripping (HS) was performed, and recorded, within five minutes of the removal of the milking units.

\section{Results}

The average yields per udder type and treatment are given in Table I. The data collected during the experiment were subjected to analysis of variance. The estimation of the difference between the treatments was based on a model mentioned by COCHRAN and Cox (r957):

$$
\begin{aligned}
& \mathrm{E}_{a}=\frac{\mathrm{I}}{n} \sum_{i=1}^{n} \frac{\mathrm{A}_{1 i}+\mathrm{A}_{3 i}}{2}-\mathrm{B}_{2 i} \\
& \mathrm{E}_{b}=\frac{\mathrm{I}}{n} \sum_{j=\mathrm{x}}^{n} \frac{\mathrm{B}_{1 j}+\mathrm{B}_{3 j}}{2}-\mathrm{A}_{2}
\end{aligned}
$$

where $\mathrm{E}_{a}$ and $\mathrm{E}_{b}$ are the differences between the treatments $\mathrm{A}$ and $\mathrm{B}$ in periods. I, 2 and 3 respectively.

The relative distribution of milk fraction per udder type treatment and period: is shown in figure 4.

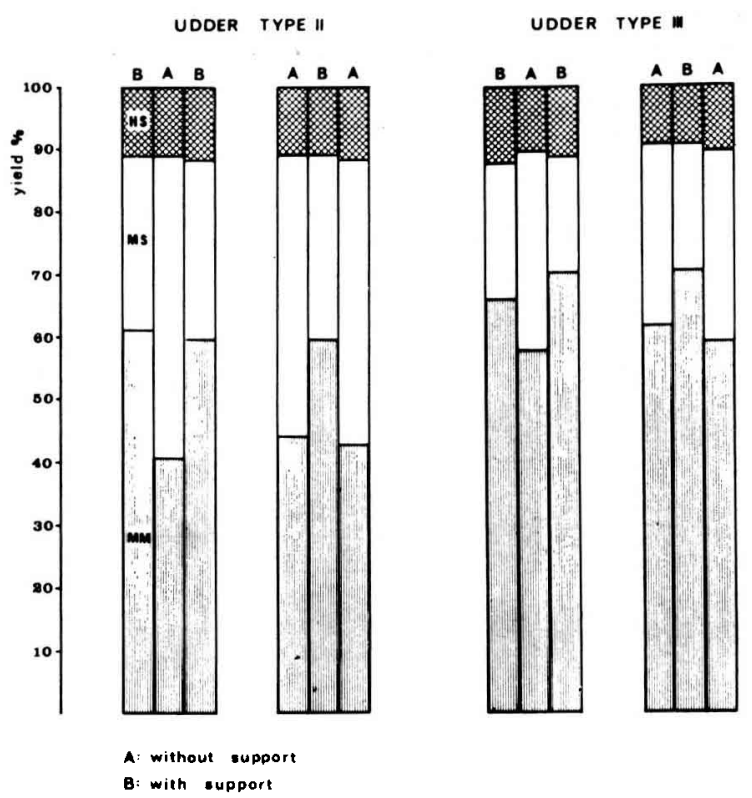

FIG. 4. - Milk fractions expressed as percentages of dairy yield.

Fractions de lait exprimées comme pourcentages de la production totale de lait. 


\section{Discussion}

Mechanical udder support had a profound effect on the relative daily amounts of the machine milk and machine stripping fractions from a practical point of view. Statistically the effect was highly significant $(p<0.00$ I and $p<0.0$ I for udder type II and III respectively). Transitions of an average of $236 \pm 59 \mathrm{ml}$ [(2I5 $+258) / 2$ ) and $\mathrm{I}_{5} 6 \pm 92 \mathrm{ml}\left[\left(\mathrm{I}_{37}+\mathrm{I} 74\right) / 2\right]$ of milk per ewe per day, from the machine stripping, to the machine milk fraction, were observed in the groups with udder type II and III respectively (Table I). Relatively, the use of an udder support increased the machine milk fraction by $5_{5} .0 \pm 2$.I p. IOo in animals with udders type II and by II \pm I.9 p. Ioo in animals with udders type III, both calculated for group performance, and by $\mathrm{I} 8 \pm 2.6 \mathrm{p}$. IOO and IO.I $\pm 2.0 \mathrm{p}$. IOO respectively, when calculated for individual performance.

The improvement achieved is smaller than that reported by SAGI and MoraG (I974) which was approximately $23 \mathrm{p}$. Ioo for animals with udders type II. Part of the difference could possibly be accounted for by the difference in the total dairy yields, which was about $200 \mathrm{ml}$ higher for the group used in the experiment reported here. However, the major cause is perhaps the difference between the two means used for supporting the udder, viz. a hand versus a mechanical arm. Supporting the udder by hand is more effective from a mechanical point of view, since the pressure exerted by the operator is adjusted according to the shape and size of the udder. Moreover, since the physiological mechanism is not yet clear, some neurohormonal processes could also have been involved. If that is so, a hand is most probably better than a mechanical device in evoking and stimulating such a process. However, the fact that the hand-stripped and total dairy yields were not affected by the treatment leads to the more likely assumption that the mechanism involved was exclusively mechanical and that central hormonal effects were not involved. If that is the case, improving the design of mechanical supporting arms could bring about further improvements in efficiency to the extent - it may be hoped - that machine stripping in dairy ewes could be substantially reduced and even eliminated.

Accepté pour publication ch mai 1978.

\section{Résumé}

\section{Soutien de la mamelle comme moyen d'améliorer le fractionnement du lait chez les brebis laitières}

L'efficacité d'un dispositif mécanique de soutien de la mamelle (fig. r) a été évaluée dans le but d'un accroissement de la fraction de lait recueillie au cours de la ire phase dela traite mécanique (lait " machine ") chez les brebis laitières. Quatre groupes de brebis présentant des mamelles des types II et III (fig. 2) ont été soumis à des séquences de traitement ABA et BAB (A sans dispositif, $B$ avec dispositif).

L'utilisation du bras de support entraine une modification importante de la part des différentes fractions du lait au cours de la traite. Un transfert significatif $(236 \pm 59 \mathrm{ml}$ et $156 \pm 92 \mathrm{ml})$ est observé du lait "égouttage machine" au lait "machine " respectivement chez les animaux ayant une mamelle des types II et III.

La quantité totale de lait et le volume de lait recueilli à l'égouttage manuel (repasse) ne sont pas modifiés. 


\section{References}

Cochran W. G., Cox G. M., 1957. Experimental Designs. John Wiley and Sons Inc. N. Y., and ed., p. I4I.

JATSCH O., SAGI R., r978. Effect of some anatomical and physiological traits on dairy yield and milk fractionation in dairy ewes, 2nd symposium on machine milking of small ruminants, Alghero 22-27 May.

SAGI R., MORAG M., I974. Udder conformation, milk yield and milk fractionation in the dairy ewe. Ann. Zootech., 23, 185-192.

Sharav A., VolCANI R., EYal E., 1962. A survey of udder conformation of Awassi sheep. Ktavim, 12, 99-107 (Hebrew). 